\title{
Por que Não uma Constituição Européia?
}

Ana Paula Tostes

Q

ual é a diferença entre a atual crise da União Européia - UE, com a resistência a sua constitucionalização, e as velhas crises de legitimidade e "déficit democrático"? Por que a União quer uma Constituição, que sabemos que é um tratado, mas que uma considerável parcela das sociedades nacionais vem apresentando sinais de resistência a ela?

Este artigo parte da hipótese de que a criação de uma "identidade coletiva européia" é um dos projetos de fortalecimento da supranacionalidade da União, e tanto a cidadania européia quanto a Constituição são instrumentos desse projeto. A “identidade coletiva" é uma importante esfera de pertencimento (Aziz, 2002), como o sentimento descrito por Benedict Anderson (1991) sobre o valor e o papel das "comunidades imaginadas". O único caminho de legitimação da cidadania européia é o da construção de uma identidade européia; e este é o principal motivo pelo qual os teóricos que defendem a emergência de uma European polity também vêm se interessando por questões de formação de identidade coletiva (Risse-Kappen, 2000; Haas, 1958; Deutsch, 1957). Por tudo isso, a análise dos percalços da fase de Maastricht (que cria a cidadania européia), e da incorporação do Tratado da Constituição, da recepção social do projeto de integração através das pesquisas de opinião pública e do comportamento do eleitorado nos sufrágios populares, concorre para o desenho de um quadro geral das condições e possibilidades da União Européia superar o atual estágio de crise.

DADOS - Revista de Ciências Sociais, Rio de Janeiro, Vol. 49, n²2, 2006, pp. 379 a 415. 
Os argumentos deste artigo procuram revelar que, no caso da UE, aspectos de supranacionalidade e de transnacionalidade devem ser compreendidos conjuntamente, na medida em que características e percalços em uma destas instâncias interferem na outra. Algumas causas de resistência aos avanços da supranacionalidade são compreendidas quando verificamos o fortalecimento das articulações transnacionais na região e, principalmente, a partir da mudança do quadro de alinhamentos entre grupos tradicionais que sempre explicaram a política européia (Smisans, 2004; Marks, Hoogle e Edwards, 2004). Uma das conclusões a que podemos chegar, quando atribuímos relações entre avanços supranacionais e transnacionais é que, enquanto a UE busca criar mais instrumentos de consolidação de sua estrutura supranacional (o Tratado da Constituição é exemplo mais perfeito disso), as articulações transnacionais se dão a partir de convergências entre grupos que resistem ao projeto supranacional por razões, em alguns casos, extremamente diferentes. Coincidem interesses entre novos ideólogos da extrema direita (Ignazi, 2003; Mude, 1996) e grupos de extrema esquerda, quando a agenda é a resistência à criação de um super-Estado europeu ${ }^{1}$.

\section{ORDEM E ETHOS}

O projeto de integração europeu é explicado por uma história de acertos e sucessos ao longo de mais de meio século de construção. Contou com a assimilação de novas regras por parte dos governos nacionais envolvidos, com a criação de uma nova instância jurídica e com um formato sui generis de organização institucional, que envolve uma coordenação de interesses intergovernamentais baseados em um interesse supranacional: o interesse comunitário ${ }^{2}$. Com tudo isso, uma importante constatação apresentada por grande parte da literatura, que avalia aspectos sociológicos da unificação européia, dá destaque à inexistência de um ethos comunitário na Europa. Debates sobre a "tese do não demos" na região da integração $^{3}$, retomados após a crise de Maastricht ${ }^{4}$ por Weiler, Haltern e Mayer (1995), vêm se revelando cada vez mais importantes para se compreender as diferenças dos Estados-membros quanto às sinalizações de resistência à integração social, à cidadania única na região e à criação de uma Constituição.

Apesar deste quadro de incongruência entre os avanços institucionais e legais da Europa integrada e da integração social no âmbito regional, parto da hipótese de que uma "política de identidade" sempre esteve na agenda de integração européia e já era preocupação do projeto ante- 
rior à União. Desde a "Europa européia" de De Gaulle ao Plano Shuman no período pós-Guerra, não se cogitava uma integração sem identidade. Contudo, só se torna mais evidente tal preocupação a partir do processo de ratificação de Maastricht (1992-93), com a busca do referendo popular para a implantação de reformas substantivas, incluindo a criação da cidadania européia. Apesar disso, a cidadania não seria útil apenas ao projeto de legitimação da União, mas principalmente ao seu projeto de eficiência e consolidação. O significado de uma cidadania, assim como o significado de uma Constituição, revelam uma inescapável conexão com aspectos da assimilação de uma nova identidade coletiva na vida cotidiana e envolvem mudanças de crenças, valores sociais e jurídicos que se desvelam na convivência civil e social dos indivíduos, na medida em que implica a substituição ou sobreposição de uma identificação política e social mais ampla do que a do Estado nacional. Se esta afirmação estiver correta e fatores como cultura e identidade puderem ser considerados relevantes para o estudo das relações internacionais ${ }^{5}$, o melhor método para se compreender os atuais percalços da integração, representados pelas recentes rejeições ao Tratado da Constituição, é o da investigação histórica e comparada dos resultados de pesquisa de opinião pública e a verificação do contexto de dificuldades que nos leve a uma melhor compreensão também da crise de Maastricht.

Neste cenário de questões a serem abarcadas, pretendo desenvolver dois argumentos centrais. O primeiro é que a criação da cidadania única européia buscou legitimar ex post a integração, na medida em que as sociedades nacionais não optaram pelos comprometimentos e constrangimentos de sua participação e controle sobre a nova política européia - e é por isso que ainda falta muito a ser pesquisado e refletido sobre a UE, e seus efeitos e conseqüências ainda estão longe de se completarem, como se vê nos atuais percalços enfrentados no processo de ratificação do Tratado da Constituição. O segundo argumento é que, em uma era de desenvolvimento de atores internacionais e transnacionais não-estatais que agem em redes e que, principalmente no caso da UE, encontraram novas formas de representação supranacional e regional e facilidades de articulação e circulação entre fronteiras nacionais, não há apenas vias de demandas legítimas, pluralistas e inclusivas de uma sociedade civil que interage em nome de interesses democráticos, mas também demandas não-democráticas e desagregadoras, bem como aqueles que defendem o fim da integração. 
Exatamente por considerar que há uma distância entre a integração de caráter econômico e legal e a integração social ou, de outra forma, entre a integração institucionalmente formalizada e a socialmente conduzida e reconhecida, é que pretendo dar especial atenção à literatura orientada por uma visão crítica da integração européia. É fundamental considerar o fato da inexistência de uma sociedade homogênea regional, para que se compreendam alguns eventos paralelos aos passos de consolidação da integração, como certas reações dos eleitores europeus, reveladas nas consultas populares, nas eleições nacionais e nas eleições européias para o Parlamento.

Além do nacionalismo de grupos de esquerda e da defesa de princípios como soberania e autonomia, uma importante "questão social" nas agendas de política doméstica e de política internacional na Europa hoje é o problema da assimilação dos imigrantes, que se reflete no recrudescimento da xenofobia européia, particularmente, na última década e meia. Este aspecto da política européia atual é importante para compreendermos por que os grupos que resistem ao projeto de cidadania e de constitucionalização são capazes de se fortalecerem reciprocamente ao misturarem argumentos e interesses tanto da extrema esquerda, socialista e nacionalista, quanto da extrema direita, xenófoba ou fundamentalista.

\section{DUAS ESTRATÉGIAS DE CONSTRUÇÃO DA UNIDADE REGIONAL: CIDADANIA E CONSTITUIÇÃO}

A União Européia está em busca da consolidação de uma consciência de valores comuns e de identidade coletiva para legitimar sua estrutura supranacional ${ }^{6}$, atualmente simbolizada na "Constituição Européia", em fase de incorporação pelos Estados-membros. Creio que a defesa da necessidade de uma "Constituição" para a UE sempre esteve ancorada nos esforços em ressaltar seus aspectos supranacionais e buscar a legitimidade social que sempre lhe faltou. Impossível é compreender a atual crise da Europa, com as recentes rejeições populares à ratificação do Tratado da Constituição, sem a observação do contexto histórico da UE, incluindo-se aí outros períodos de crises como na ocasião da ratificação do Tratado de Maastricht.

\section{A Criação da Cidadania e a Crise de Maastricht}

Na cidade holandesa de Maastricht, chefes de Estado reunidos em sessão do Conselho Europeu (em 1991), aprovaram o projeto de um tratado 
para a UE com o objetivo claro de dar um passo significativo no processo de aprofundamento e ampliação da integração. Além de traçar metas para uma maior integração econômica e monetária, neste tratado foi criada a "cidadania européia". Na tentativa de promover importantes passos no projeto de integração, entretanto, o processo de ratificação do Tratado de Maastricht fez revelar um desconhecimento popular e um significante grau de resistência e precaução quanto ao modelo de integração que avançava.

Enquanto o Tratado de Maastricht pretendia representar o grande passo para o fortalecimento da união política na região, seu processo de incorporação fez surgir a mais profunda crise da integração. O grande símbolo da crise foi a rejeição popular dinamarquesa, numa das primeiras consultas populares sobre qualquer passo da integração desde o seu início. A Dinamarca, que tinha sérias restrições à unificação, preferiu entregar à sociedade o poder de decisão final em favor da sua adesão à UE, levando em conta conseqüências que implicariam mudanças no cotidiano social e na política doméstica de sua nação. A resposta do eleitorado caiu como uma bomba nos planos de integração, ancorados em discursos infundados de democratização e de legitimidade social. O primeiro "não" dos dinamarqueses desvelou as razões que faziam com que alguns Estados temessem a conscientização social a respeito das decisões governamentais que processavam, até então, a integração. Podemos afirmar que a "crise de Maastricht" surge em função do exemplo dado pelo governo dinamarquês ao optar pela consulta popular sobre a integração. Dentre os danos de Maastricht, revelou-se que havia profundas divergências existentes entre os anseios populares e os interesses governamentais na unificação.

O resultado do referendo francês não redimiu esta crise, pois apenas $51 \%$ dos votantes no referendo francês disseram "sim" ao tratado. Paralelamente, a opinião pública alemã e a britânica deixaram clara uma considerável oposição, fazendo com que, de todos os tratados reformadores da União, esse tenha sido o de parto mais difícil (Hartley, 1988:7). Curioso nesta história é que se esperava exatamente o contrário: um momento de fortalecimento do projeto e de legitimação social do seu aprofundamento.

O debate acadêmico predominante na Europa ainda dá destaque ao "déficit democrático" da União, agravado após Maastricht; ou seja, um tratado que se sustentava em uma retórica democrática (porque criava 
uma cidadania única e diminuía os entraves à livre circulação de pessoas e trabalhadores) promoveu uma curiosidade mais crítica quanto à toda empreitada da integração. Por isso podemos dizer que o Tratado de Maastricht produziu alguns efeitos não-antecipados, principalmente, porque causou uma crise de legitimidade da União exatamente em um momento de aprofundamento do processo de integração. Pretendendo resolver alguns problemas democráticos no âmbito das instituições comunitárias e esperando atribuir legitimidade ao processo de integração, considero que Maastricht acabou por evidenciar e fortalecer ao mesmo tempo uma crise democrática mais profunda e não reformável institucionalmente: o desconhecimento e a distância das sociedades nacionais do projeto europeu em curso. Ao longo dos processos de ratificação de Maastricht nos Estados-membros, ficou claro que as populações dos países-membros não estavam até então conscientes da integração e não tinham informações suficientes a respeito das instituições comunitárias, sua importância e competência. De fato, o desconhecimento das mudanças concretas da política nacional promovidas pela integração européia, bem como o papel e importância das instituições da UE, ainda são de desconhecimento majoritário entre os cidadãos.

Pesquisas do Eurobarometer do ano de $2000\left(\right.$ EB no 53, 2000) ${ }^{8}$ avaliaram o conhecimento popular das instituições européias a partir de sondagens que envolvem várias perguntas sobre as principais instituições da União: o Parlamento Europeu, a Comissão, o Banco Central Europeu, a Corte de Justiça, o Conselho de Ministros, a Corte de Auditores, o Comitê Econômico e Social, o Ombudsman Europeu e o Comitê das Regiões.

Os resultados demonstram que, na avaliação popular européia, o Parlamento Europeu é a instituição que exerce o papel mais importante na região da integração e o Conselho de Ministros fica em quinto lugar. Foi perguntado também, dentre as instituições, quais eram mais conhecidas pela opinião pública européia, e o Parlamento Europeu apareceu mais uma vez como a instituição da qual "mais se ouviu falar", enquanto o Conselho manteve o quinto lugar no ranking. Sabendo-se o pouco poder exercido pelo Parlamento e o importante poder decisório exercido pelo Conselho, fica fácil concluir, diante dos resultados apresentados nos gráficos 1 e 2, o quanto cidadãos europeus estão mal informados a respeito das conseqüências e do alcance político do Conse- 


\section{Gráfico 1}

\section{O Papel das Instituições e Organizações na Vida da UE}

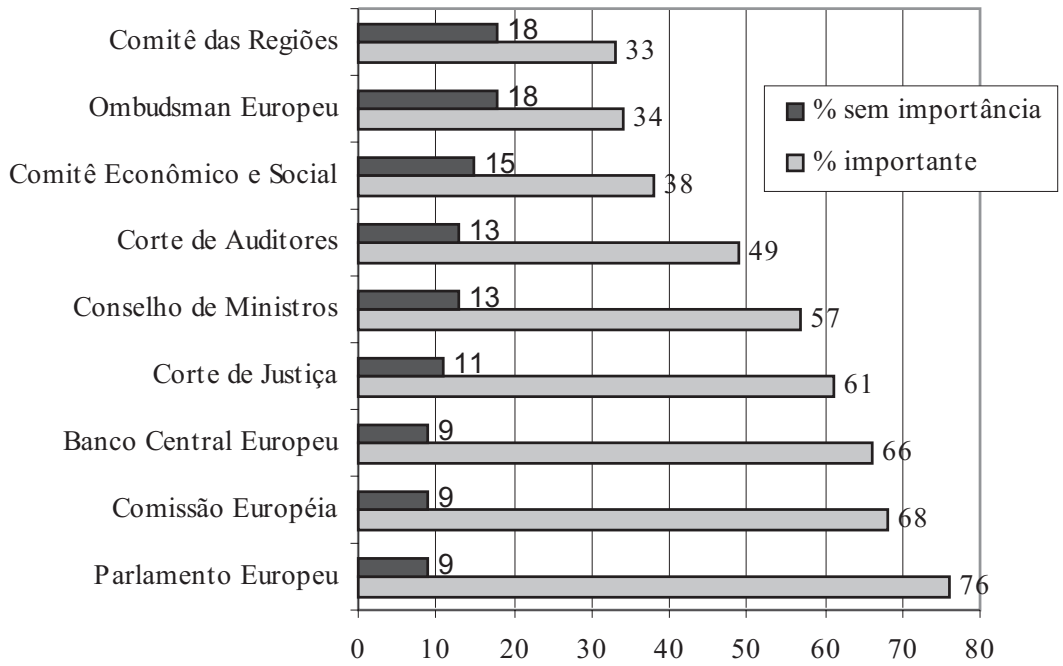

Fonte: Eurobarometer, EB nํㅗ 53, 2000.

\section{Gráfico 2}

Você já Ouviu Falar de ...? (UE 15)

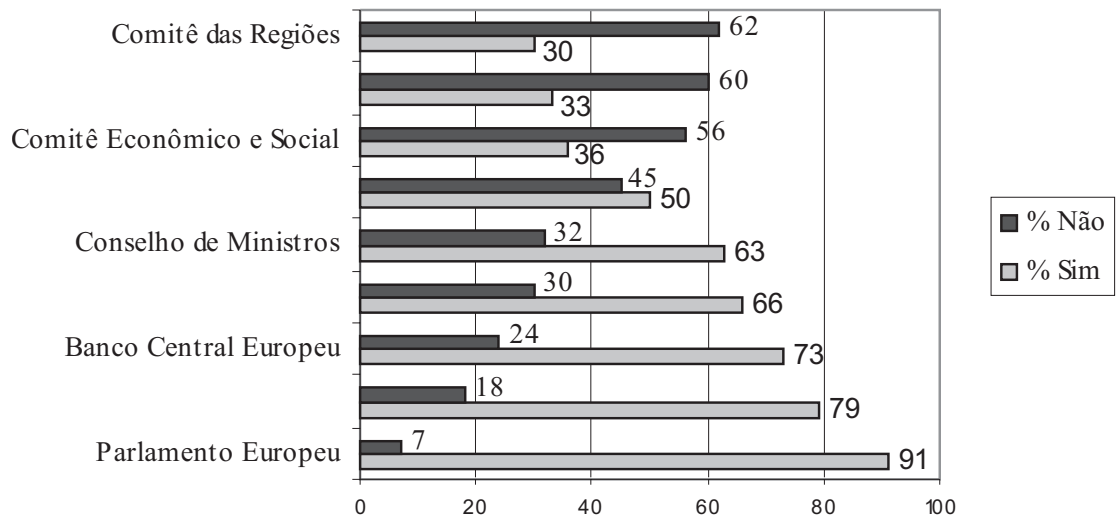

Fonte: Eurobarometer, EB nํㅗㄹ 2000. 
lho, do papel da Corte de Justiça européia e dos limites do poder do Parlamento Europeu'.

No período de Maastricht, a busca pela legitimidade da integração revelou-se pela decisão de raros países em realizar referendos para a ratificação do tratado, exatamente porque consideraram que o conhecimento e a participação popular do importante passo a ser dado pelo processo de integração na ocasião seria de fundamental importância. Entretanto, já naquela ocasião, verificava-se nos debates políticos que a divisão entre esquerda e direita não era mais uma perspectiva dimensional simples na política européia. De fato, desde a década de 1990 já havia cisões entre grupos de direita e entre grupos de esquerda em torno da avaliação da integração e do posicionamento sobre o seu encaminhamento. Muitos que defendiam o fim da integração alegavam uma possível perda de soberania das nações, e outros não admitiam a integração social, abertura de fronteiras e facilitação do processo migratório na região por conta da criação da cidadania única européia.

Em meio a este debate, o povo dinamarquês rejeitou, em primeiro referendo, a ratificação de Maastricht ${ }^{10}$. Isto deflagrou uma crise notória, refletida na opinião pública, sobre o projeto de aprofundamento de união política. Afinal, podia-se perguntar por que o povo dinamarquês não quer mais se integrar à região? Qual é o custo da integração e o que há de negativo neste tratado a ponto de o povo rejeitá-lo?

Em meio à crise dinamarquesa, surgiu a crise britânica (na ocasião, nas mãos do seu primeiro-ministro John Major), que se revelou como sendo o próximo ponto débil da integração. Desde o momento em que a Inglaterra decidiu esperar pelo segundo plebiscito da Dinamarca para se resolver quanto à ratificação de Maastricht ${ }^{11}$, uma série de razões céticas à integração se alinhava com mais autoridade e propriedade. Para se somar a este quadro de fragilidades, na ocasião do período de ratificação de Maastricht (de 1992 a 1993), o Reino Unido assumiu, no segundo semestre de 1992, a presidência rotativa da União sem qualquer qualidade de liderança.

Em geral, os "eurocéticos"12 conservadores e os trabalhistas anti-europeus ingleses mobilizavam-se em torno de duas questões básicas: aqueles (que tinham como porta-bandeira Margaret Thatcher) demandavam consulta popular para a ratificação do Tratado de Maastricht, enquanto estes exigiam que o exame pela comissão do projeto de lei que incorporava o tratado fosse feito apenas depois que a Dinamarca 
decidisse seu posicionamento diante dos termos do tratado (Tostes, 2004:116-117), como de fato ocorreu. Para o agravamento da situação, naquele mesmo período, na Alemanha, também apareceram objeções constitucionais feitas pela influente Corte Constitucional Federal da República Alemã. Magistrados germânicos mostraram-se renitentes no que dizia respeito à primazia do direito comunitário em relação ao direito nacional, princípio jurisprudencial já aplicável naquelas alturas aos Estados-membros. A conseqüência da persistência da supremacia constitucional alemã foi que este país se tornou o último Estado-membro a depositar o instrumento de ratificação de Maastricht, que só entrou em vigor efetivamente em 1993.

\section{RESISTÊNCIA À CONSTITUIÇÃO EUROPÉIA E PROBLEMA DA IDENTIDADE COLETIVA}

Podemos identificar razões semelhantes às que levaram à crise de Maastricht na resistência ao projeto de criação de uma Constituição européia atualmente. Sabemos que o processo de mais de meio século de integração não obteve participação popular, entretanto, sabemos também que valores e crenças são construídos socialmente e podem gerar estratégias de ação coletiva. Assim, a criação de uma cidadania e de um ordenamento jurídico de caráter regional visa reforçar, além dos instrumentos legais e institucionais, características de similaridades e de coincidências de idéias, interesses, crenças e valores entre os cidadãos que integram os Estados-membros da UE.

Estes novos esforços do governo comunitário ficam explicados, principalmente, menos pelo que a Constituição européia pode, de fato, trazer de novo para os poderes exercidos pelas suas instituições, e mais para promover uma certa comoção nas sociedades dos Estados-membros em nome da legitimação do processo de integração e garantir, com isso, maior eficácia para as suas políticas. O projeto de construção de uma identidade social e o reconhecimento da união política e legal por parte das sociedades nacionais é o que justifica a preocupação que as instituições européias têm tido em estabelecer uma "Constituição" que, como sabemos, trata-se de um tratado internacional. Como todo tratado, este deve ser incorporado segundo as regras constitucionais de cada Estado e não é incomum que, em função da sua abrangência política, as constituições determinem a consulta popular. Mas antes ainda do conteúdo do tratado em questão ser conhecido, foram feitas pesquisas de opinião pública a respeito da aceitação de uma Constitui- 
ção na região. Observando-se os resultados destas pesquisas, verifica-se que a aceitação da criação de uma Constituição sempre foi alta, ao mesmo tempo que sua rejeição sempre foi, também, crescente.

No Gráfico 3, agreguei os resultados das pesquisas do Eurobarometer que investigaram o apoio à Constituição ao longo dos anos de 20002005, o que nos permite observar que, apesar da queda do apoio popular à Constituição ${ }^{13}$, o ano de 2004 apresentou uma ruptura nesta tendência. Os resultados estão agregados, pois revelam as médias dos 15 Estados-membros. Porém, quando verificamos separadamente os resultados nacionais, podemos ver que há variações importantes que explicam comportamentos e expectativas diferenciadas que não serão tratadas neste artigo. Podemos concluir que no ano de 2004 há uma mudança na percepção popular quanto à aceitação da Constituição por este ter sido o principal ano de discussão sobre o conteúdo do projeto da Constituição pelas sociedades e pelos meios de comunicação europeus em geral. A adoção do Tratado da Constituição deu-se no Conselho de Roma em 29 de outubro de $2004^{14}$. Ao mesmo tempo, entretanto, podemos notar no Gráfico 3 que a rejeição à adoção de uma Constituição européia vem sendo ininterruptamente crescente desde 2000 (6\% de rejeição) até o início do processo de incorporação, em 2005 (23\% de rejeição).

Ainda assim, o apoio inconteste à Constituição é curioso quando observamos pesquisas que demonstram o desconhecimento de seu con-

\section{Gráfico 3}

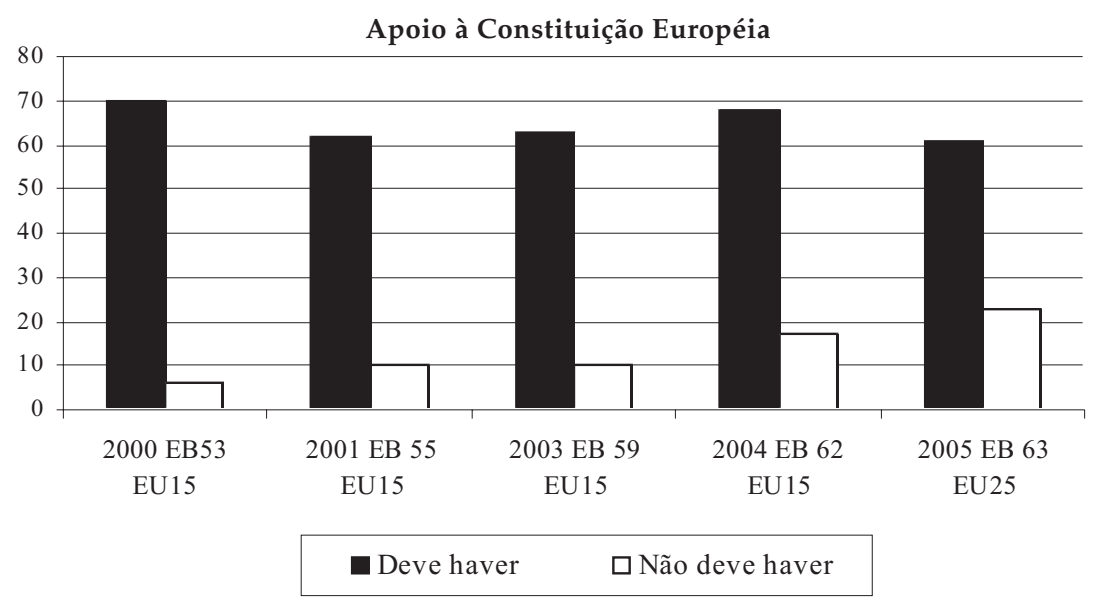

Fonte: Eurobarometer Reports (2000; 2001; 2003; 2004; 2005). 
teúdo - apenas para exemplificar, o Centro de Investigações Sociológicas na Espanha divulgou os resultados de uma pesquisa em 2005 a qual revelou que 90,9\% dos espanhóis ignoram o que a nova Constituição européia propõe, embora $51,2 \%$ estivessem dispostos a votar pelo "sim" (Oswald, 2005:27). Os resultados das primeiras pesquisas de 2005 do Eurobarometer já apontavam que 56\% dos europeus admitiam saber pouco sobre o Tratado da Constituição européia, e que 33\% sequer tinham ouvido falar dele. Contudo, apesar desta absoluta ignorância, é possível verificar uma infundada boa vontade quanto à adoção da Constituição. O que podemos concluir destes resultados é que eles revelam a importância simbólica da idéia de Constituição, independentemente das condições e cláusulas do tratado em questão. Revela-se assim, ainda, que a cúpula da União está absolutamente certa em designar como "Constituição" um tratado que busca alçar legitimidade no processo atual de unificação política. A importância histórica nacional das constituições sempre nos leva a pressupor laços de legitimidade e uma organização institucional democrática com mecanismos de participação e de realização de justiça.

Fica mais claro, com tudo isso, a compreensão sobre a idéia de Constituição, que marca simbolicamente esse Tratado da União Européia. Há neste atual projeto da integração regional européia a pretensão de fortalecer uma noção de território e identidade social comuns. Está na base da condição de se estabelecer uma "Constituição", entretanto, a existência de uma cidadania comum no território da União, e esta, embora implementada juridicamente há mais de uma década, vem sendo assimilada muito lentamente desde a sua invenção. Problemas identificados na ocasião da ratificação de Maastricht permanecem sem solução até a fase da ratificação do Tratado da Constituição, como o da aceitação de uma identidade coletiva comum regional.

Institutos de pesquisa de opinião pública europeus vêm se debruçando também sobre o mapeamento dos graus de aceitação da cidadania européia e divulgam, periodicamente, diagnósticos sobre a percepção social da relação entre a cidadania nacional e européia ${ }^{15}$.

Comparando-se o resultado do Gráfico $4 \mathrm{com}$ as respostas de outra pergunta realizada na mesma pesquisa (Eurobarometer, EB no 59, 2003) sobre se "é ruim" fazer parte da UE, verificamos que os países que apresentaram percentuais mais altos sobre a má avaliação quanto ao pertencimento à União, ou seja, Suécia, Reino Unido e Áustria, são 


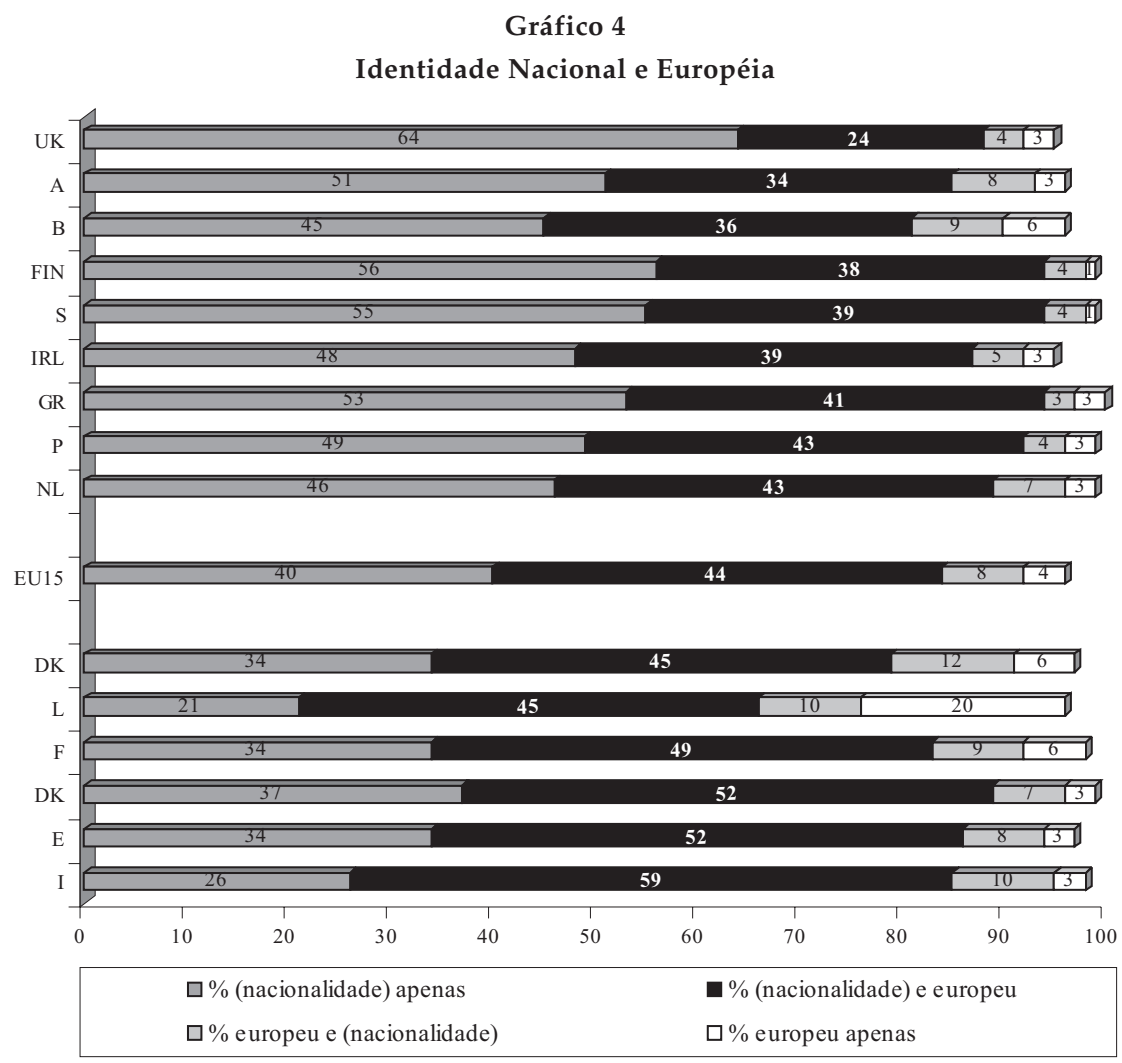

Fonte: Eurobarometer, EB nº 59.1, 2003.

exatamente os mesmos Estados-membros que valorizaram mais a sua identidade nacional (como verificamos a partir dos resultados anteriores). A Grécia é um caso de destaque, pois possui um sentimento nacional e patriótico muito forte, que se apóia na convicção de que ela é o berço da civilização ocidental. Da mesma forma, a Finlândia tem uma história de resistência à dominação e tende a proteger-se em sua identidade nacional. Em outro extremo estão os países que ingressaram na União em 2004; estes demonstraram um sentimento de nacionalidade muito fraco. Dentre os resultados mais significantes neste sentido, destacam-se os da Estônia e da Hungria (39\%), países que estão em busca de uma nova identidade, olhando mais para possibilidades futuras do que para seu recente passado de hegemonia russa.

A ênfase na identidade nacional é aceita por $85 \%$ dos cidadãos, tanto os da Europa dos 15 quanto dos 25. A idéia de uma identidade coletiva 
que pretenda substituir, sobrepor ou mesmo mesclar com a identidade nacional, tomando por base um alto grau de compartilhamento de aspectos culturais (raça, língua, religião, tradição etc.), não parece ter mais espaço na região européia. Qualquer assimilação só parece possível no âmbito de coincidências políticas e interesses jurídicos e civis. $\mathrm{O}$ único resultado absolutamente discrepante é o relativo a Luxemburgo, que demonstra que seus cidadãos assumiram plenamente a identidade civil estratégica e politicamente construída - sem qualquer nuance culturalista, 20\% dos cidadãos de Luxemburgo pesquisados declararam sentirem-se "só europeu".

Qualquer debate anterior ao alargamento, ainda sobrevivente, sobre a possibilidade de se construir uma identidade coletiva européia alimentada por aspectos materiais e culturais, perde completamente o fio da razão argumentativa com a entrada dos países do Leste europeu na UE. Com a entrada de Estados-membros do Leste europeu na União, tornou-se incontestável que apenas uma noção de identidade coletiva baseada em coincidência de perspectivas civilizatórias e políticas (tese do nacionalismo construtivista ou político) pode ter lugar no caso da UE atualmente.

\section{DEBATES TEÓRICOS PRECURSORES: A CONSTITUIÇÃO DE MODELOS NACIONAIS}

Dois modelos dominantes de nacionalismo povoaram a história da formação dos Estados nacionais: um que pode ser designado como "culturalista" e outro como "político". O primeiro, como a própria designação indica, é aquele que valoriza os aspectos culturais da história comum de um povo (Kohn, 1963). Tradição, religião, raça, língua e outros aspectos materiais da vida e da história social definem uma identidade comum. Neste caso, os ideais nacionais geram e são gerados por uma carga emocional mais voltada para aspectos particulares e espontâneos ${ }^{16}$.

O segundo modelo incorpora aspectos políticos e expectativas de ordem e de direito comuns estrategicamente organizados e construídos socialmente. Assim, é a partir da criação de normas, do fortalecimento de costumes e da modelação de instituições que lhes dêem sustentação operacional, é que se fortalecem também os laços que se pretende valorizar neste caso. São dessa forma incorporados aspectos políticos e expectativas de ordem e de direito comuns com a criação de normas e, ainda, a defesa de princípios gerais e universais de coexistência pacífi- 
ca na esfera pública e no cotidiano da vida civil. Já o conceito político de nação, enquanto um tipo ideal de identidade coletiva, valoriza a integração política dos cidadãos em busca da liberdade individual de todos. A existência de privilégios de base aristocrática em uma mesma comunidade política é incompatível com a generalidade das leis e a igualdade pleiteada pelo "nacionalismo político" (ou jurídico). Este nacionalismo é comparável ao tipo de identidade coletiva possível em uma região em que coexistem povos oriundos de tradições históricas diferentes, como é o caso da UE. Isto porque, para o nacionalismo de tipo político, importam menos os aspectos culturalistas peculiares do povo e mais um objetivo político comum: ser um cidadão participante das diretrizes do governo.

A idéia de "nação", que se revela no Terceiro Estado no período da Revolução Francesa, persegue o sentido da "vontade geral" em Rousseau, para quem o governo só élegítimo se realiza a aspiração coletiva dos cidadãos - daí a necessidade de um conceito orgânico que traduzisse uma simbologia de universalidade e de exclusividade ao mesmo tempo. A superação dos interesses particulares (minoritários) justifica-se, neste caso, pela composição de um "espírito nacional" e pela prevalência de um interesse geral real sobre as divergências locais ${ }^{17}$.

Independentemente da possível distinção entre o nacionalismo cultural e o político, o que importa na comparação com a constituição de uma identidade coletiva no seio da UE é que a noção de "pertencimento" a um corpo coletivo é que legitima algum tipo de cooperação e coexistência. No caso da UE, a percepção, crença e idéia de "pertencimento" a uma sociedade plurinacional de características tão heterogêneas espera por ser construída, em função dos interesses que estão em jogo no processo de integração.

\section{A Estratégia da Construção}

Até então, desenvolvi os argumentos que focalizam o fato de que uma identidade coletiva pressupõe o compartilhamento de valores subjetivos, de forma que os indivíduos se sentem parte de uma mesma comunidade por eles imaginada. Historicamente, a construção dos tipos nacionalistas e, atualmente, a experiência européia, foram considerados sob a ótica da construção involuntária ou não de laços de reconhecimento mútuo. É preciso acrescentar, no entanto, que é natural a este processo que os integrantes de uma dada "comunidade imaginada" 
compartilhem também sentimentos de diferença em relação a outras comunidades (in-group e out-group). Para compreender melhor o processo de construção de identidade, a abordagem construtivista tornou-se, atualmente, uma ferramenta metodológica poderosa.

Sem se opor ao realismo ou ao liberalismo, a abordagem construtivista que tem sido descrita e explicada por Alexander Wendt não como uma teoria política, mas uma teoria social, vem sendo aplicada empiricamente por autores como Risse-Kappen (1995; 2000) e outros (Adler, 1992; Finnemore,1996) na compreensão do problema da identidade coletiva em geral e do caso da identidade européia em especial. O construtivismo desafia fundamentos epistemológicos dos paradigmas das relações internacionais, não para se opor a eles mas para sintetizar possibilidades de análise que têm importância na pesquisa empírica (Adler, 1999:206-207). Segundo Adler (idem), o construtivismo é capaz de iluminar características importantes, antes enigmáticas, da política internacional (Wendt, 1999). A importância das idéias, dos símbolos e das crenças que forjam solidariedades e geram instituições perpassa a história dos Estados e, naturalmente, a da UE.

Sabe-se que a constituição dos Estados modernos está baseada na idéia de que o Estado-Nação se funda em um sistema de símbolos e de identidade compartilhada ${ }^{18}$. Assim, a dimensão simbólica do poder do Estado "sustenta as necessidades morais e éticas dos cidadãos, não apenas as materiais" (Krasner, 1984:233 apud Laffan, 1996). A relação entre identidade e política é exemplificada pela história da busca de legitimação dos Estados modernos a partir da noção de nação, em alguns casos reforçando aspectos étnicos, de raça e religião (caso da Alemanha) e em outros aspectos políticos e jurídicos traduzidos em valores cívicos que buscam evitar a diferenciação do cidadão e da pessoa humana através de particularidades de suas escolhas e/ou origens religiosas ou culturais (é o típico exemplo da França).

Segundo os "europessimistas" ou "eurocéticos", a integração em termos de identidade coletiva é impossível, na medida em que a identidade nacional será sempre particularmente fundamental para os cidadãos. Por outro lado, é preciso levar em conta que a construção da identidade é um longo processo, que perpassa vários níveis da vida em sociedade, como a cultura, a arte, a literatura, a religião, produzindo imagens e analogias que não se explicam por mecanismos racionais - mas se experimentam pela emoção (Walzer, 1967) e com o tempo. Em um 
ensaio clássico sobre o tema, Walzer (idem) enfatiza que a atividade simbólica é um "processo criativo", que não tem nada de lógico ou de necessário - é uma estratégia de atribuição de unidade, organização, significação, personificação. Do mesmo modo, uma mudança no referencial da identidade coletiva pressupõe um processo de transformação no "equipamento simbólico", na "mentalidade coletiva", na "episteme social", na personalidade. Walzer (idem:194) descreve ainda a política como uma arte de unificação: de muitos ela faz um - e a atividade simbólica seria nossa forma mais importante de reunir as coisas, intelectualmente e emocionalmente, superando assim o isolamento e mesmo a individualidade. Neste quadro, o Estado é invisível; ele deve ser personificado antes de ser visto, simbolizado antes de poder ser amado, imaginado antes de poder ser concebido (ibidem).

A tentativa da União Européia de romper com o modelo nacional como modelo privilegiado de identidade coletiva e de criar a possibilidade de uma outra dimensão de identificação coletiva em larga escala, por ser algo totalmente inexplorado, certamente, resulta em conseqüências imprevistas. Exatamente, pela sua importância, ao mesmo tempo em que a Europa unificada está em busca de um princípio legitimador para a sua política supranacional, verifica-se uma exacerbação dos nacionalismos e dos localismos (Laffan, 1996; Smith, 1992; Jansson, 1997; Eisenstadt e Giesen, 1995; Giesen, 1999 dentre outros).

Enfim, é incontestável a relevância do conceito e da idéia de nação, que vem funcionando como tipo ideal weberiano para justificar modelos autônomos de organização e legitimação política, a partir do reconhecimento de uma identidade coletiva nacional. A história da valoração do conceito de nação é a prova da aceitação deste modelo, que vem se revelando um eficiente fator de agregação, assim como o conceito de nação vem sendo usado tanto em prol da liberdade, quanto do totalitarismo e da tirania; tanto em doutrinas democráticas, quanto em doutrinas imperialistas (Tostes, 2001).

\section{MODELOS DE IDENTIFICAÇÃO NA EUROPA UNIDA}

Para melhor interpretar as pesquisas da opinião pública européia que vêm sendo responsáveis pela mensuração da recepção social das medidas de integração, no que se refere principalmente à auto-avaliação popular sobre identidade nacional (nacionalismo) e supranacional (periodicamente sondada pelo Eurobarometer), podem-se utilizar catego- 
rias de análise propostas pela literatura que se debruça sobre o tema da identidade na Europa, como os inúmeros trabalhos de Thomas RisseKappen, do Instituto Universitário Europeu (IUE-Florença). RisseKappen (2000) apresenta três "modelos de identificação" que são três possibilidades de construção de identidade coletiva na Europa, e tais modelos se assemelham às percepções investigadas nas sondagens do Eurobarometer. Ou seja, o autor criou uma tipologia para as possíveis reações diante da oferta de mais de uma identidade coletiva, considerando-se circunstâncias e preferências, com enorme capacidade explicativa para as principais pesquisas de opinião publica realizadas na Europa atualmente.

O primeiro modelo é um tipo de jogo de "soma zero", ou seja, este se dá quando a identificação do indivíduo com um grupo implica, necessariamente, a rejeição de outras identificações. O segundo modelo é do layer cake, que atribui às pessoas e grupos sociais múltiplas identidades que se acumulam e muitas vezes se hierarquizam. O terceiro modelo é o do marble cake, que sugere uma "fluidez" e um "emaranhamento" entre as referências de identidade, a ponto de não se conceber uma sem a outra.

As duas últimas concepções modelares atribuem múltiplas referências de identidade de acordo com o contexto. No entanto, o modelo de layer cake pressupõe uma sobreposição ou ordenação de preferências e camadas, enquanto, no último modelo, se reconhece uma duplicidade de identidades e interesses mesclados. Pode-se dizer que são esses três modelos que vêm sendo levados em consideração nas sondagens sobre o tema da identidade européia como as retratadas no Gráfico 4. Foi perguntado aos cidadãos: i) se se sentiam exclusivamente nacionais de seus países; ii) se se sentiam nacionais, mas também europeus (com mais ênfase à identidade nacional); iii) se se sentiam europeus, mas também nacionais (com mais ênfase à identidade européia) e iv) se se sentiam exclusivamente europeus.

A mensuração da aceitação de uma identidade "só nacional" ou "só européia" (perguntas i) e iv) da sondagem) segue, em ambos os casos, o modelo de um "jogo de soma zero" de Risse-Kappen (2000). Levando-se em conta que os principais institutos de opinião pública européia mantêm há décadas tal tipo de levantamento atualizado e sempre baseado nas mesmas variáveis de análise de opinião pública, a principal utilidade que atribuí a esta forma de sondagem foi a da mensura- 
ção do grau de rejeição, mais do que o de aceitação, de uma identidade coletiva européia. Isto porque, a expectativa dos idealizadores da União não é realmente a de ver os cidadãos europeus abandonando suas identidades nacionais e sentindo-se "só europeus", e sim a de avaliar o grau da recepção social da identidade coletiva supranacional. De outra forma, é o modelo de layer cake que se espera implementar, no sentido de que camadas de identificação são possíveis sem que procurem se sobrepor ou substituir uma à outra. A referência a uma identidade política e não cultural ou racial é totalmente compatível com esta visão analítica. O modelo mesclado é interessante se quisermos compreender bem, por exemplo, a perspectiva francesa de identidade coletiva que, historicamente, identifica a Europa com a França como se houvesse uma razão comum que explicasse a tradição histórica humanista da Europa ocidental - as mesmas razões que explicam a resistência britânica que, também por considerar a Europa continental muito caracterizada pela influência francesa, se auto-afirma como um produto europeu à parte e sui generis, o qual não se contrapõe às relações estreitas com os Estados Unidos, mas ao contrário, procura legitimar uma identidade comum e opiniões e interesses políticos convergentes.

Para ajudar a compreender as eventuais resistências à composição, coexistência ou sobreposição de dois vínculos de cidadania na região européia, devemos considerar que há uma relação entre a recepção de uma identidade social (nacional e européia) com a conscientização de um vínculo jurídico e civil que atribui cidadania. Embora a idéia de cidadania não necessariamente se relacione com a de nacionalidade, no caso da União Européia, a aceitação da cidadania regional implica a aceitação de uma mais estreita relação cotidiana e social com indivíduos de outras nacionalidades nos territórios dos Estados-membros. Neste caso, particularmente, a cidadania européia implica um questionamento sobre interferências culturais e tolerância entre indivíduos multinacionais em um mesmo território.

\section{MUDANÇAS NAS DIMENSÕES DA POLÍTICA EUROPÉIA?}

Uma importante observação a fazer é que a grande maioria dos tratados que constituiu a integração européia não sofreu ratificação popular na maioria dos Estados-membros. Entretanto, é curioso perceber que, nas situações em que isto ocorreu, algumas manifestações de resistência ganharam voz e espaço. Por que isso se deu? 
O Tratado de Maastricht foi rejeitado em primeiro referendo pelo povo dinamarquês em 1992 (primeiro caso de consulta popular); o Tratado de Adesão à UE foi rejeitado em 1999 pelo povo norueguês, em raro caso de consulta sobre a decisão a esse respeito; o Tratado de Nice foi rejeitado (também em raro caso de consulta popular sobre este Tratado) pelo povo irlandês em 2001 e, atualmente, o Tratado de Roma (mais conhecido como Tratado da Constituição) foi rejeitado pelos povos holandês e francês. Por que a busca da participação e da legitimidade social para os passos de consolidação da União Européia sofreu tantos abalos?

A escolha da consulta popular como meio de legitimação da integração por parte de Estados-membros foi decisão de política doméstica, em função do grau de comprometimento dos governos nacionais com a legitimidade de suas políticas (Franklin, Eijk e March, 1995; Wallace e Smith, 1995). Sendo assim, países como a Dinamarca, a Noruega, a Irlanda, a França e, recentemente, a Holanda, só para exemplificar, consideraram a consulta popular fundamental em situações variadas em que o processo de integração se intensificava e, como dito anteriormente, com a chamada da população à participação vieram também resistências e mesmo rejeições. Vozes de resistência obtiveram condições de obtenção de ressonância na medida em que os meios de comunicação e veiculação de informação e formação passaram a tomar conhecimento e comentar o processo de integração, suas condições, possibilidades e conseqüências. Falta ainda compreender estas vozes de resistência, pois elas não parecem uníssonas, visto que razões diferentes orientam o discurso que rejeita a integração ou os caminhos que ela tem seguido. Para compreendermos a resistência à integração, precisamos nos voltar para a tradicional divisão ideológica européia e identificar suas mudanças.

A literatura e os debates acadêmicos sobre os problemas da integração européia vêm apontando o fato de que a União Européia é um projeto centrista europeu, criado pelos partidos do mainstream: social-democratas liberais, democratas-cristãos e conservadores; ou seja, partidos que vêm dominando a política européia nas instâncias nacionais e regionais (Hix e Lord, 1997; Marks, Wilson e Ray, 2002; Taggart, 1998). Esta é uma razão que contribui para a compreensão do fato de que os partidos que se opõem à política nacional estendem essa oposição à rejeição manifesta à aceleração e consolidação do projeto europeu. 
Tradicionalmente, a estrutura partidária européia podia ser entendida a partir de duas dimensões de competição: esquerda/direita ou GAL/TAN (Green/Alternative/Libertarian -- GAL e Traditionalism/Authority/Nationalism - TAN). Contestações à visão clássica da perspectiva econômica da competição política geraram debates também clássicos sobre o exercício da democracia (Bartolini e Mair, 1990; Lipset e Rokkan, 1967 apud Marks et alii, 2004:3). No contexto dos debates sobre estas duas dimensões tradicionais de competição partidária européia, podemos resumir que a primeira dimensão (esquerda / direita) é econômica, pois se refere à medida de regulação da economia, interferência do governo na distribuição de renda, propriedade, welfare state. A direita prioriza liberdade econômica e individual, e a esquerda, igualdade econômica. Por outro lado, a segunda dimensão de competição é vista pelo seu caráter cultural, logo não-econômico, já que privilegia visões da política que se fortaleceram a partir da década de 1970 e no contexto da busca de novas ideologias políticas contestatórias do liberalismo (Flanagan, 1987; Flanagan e Lee, 2003; Franklin, 1992; Inglehart, 1977; Kitschelt, 1988 apud Marks et alii, 2004:2).

Este artigo pretende destacar que há novos elementos de interferência no quadro das dimensões partidárias européias em função do processo de integração política. A criação de novas instituições, novas burocracias e novos interesses que se articulam desde o exercício de poder político no âmbito das instituições faz com que um novo espectro político se revele nas tendências tradicionalmente identificadas entre grupos simpatizantes da esquerda e do GAL (em geral alternativos) ao mesmo tempo ou da direita e do TAN (em geral conservadores). É preciso conferir o grau de mudanças catalisadas pelas novas tendências na distribuição de preferências partidárias e ideológicas e as novas variáveis de análise que decorrem das expectativas da integração e das razões que levam às restrições em relação a ela.

O cenário dos novos aspectos da política européia tem levado alguns centros de pesquisa sobre a integração ao mapeamento das motivações, resistências e interesses na política da integração. Pesquisas inéditas têm sido feitas no Chapel Hill Center, Centro de estudos europeus ligado a University of North Carolina, para analisar esse quadro de transformações e impactos da alocação ideológica de partidos dos Estados-membros da União Européia. Os resultados já revelam que existem muitas novidades a serem mais bem exploradas no seio do novo debate político europeu ${ }^{19}$. A relação lógica que sempre houve en- 
tre as duas dimensões direita / esquerda e alternativos/conservadores (GAL/TAN) confirma-se por um lado, ou seja, os partidos de esquerda tendem a ser alternativos, e os conservadores tendem a ser de direita. Mas, por outro lado, novas questões são trazidas pelo projeto de regionalismo econômico e político: questões de desenvolvimento, gênero, participação e cultura são fortemente associadas às novas dimensões da política ${ }^{20}$. Uma das conclusões a que nos leva a pesquisa é que a alocação de um partido entre GAL/TAN é associada ao apoio às políticas relacionadas à da UE e é consideravelmente mais importante, atualmente, do que a oposição entre direita e esquerda. Uma diferença, entretanto, é encontrada no alinhamento entre os países da Europa ocidental e os países da Europa do centro e do leste, com uma tendência que se mostra evidente na comparação dos gráficos 5 e 6 .

\section{Gráfico 5}

Dimensões da Competição Partidária e Posição sobre a Integração Européia no Centro e Leste Europeu

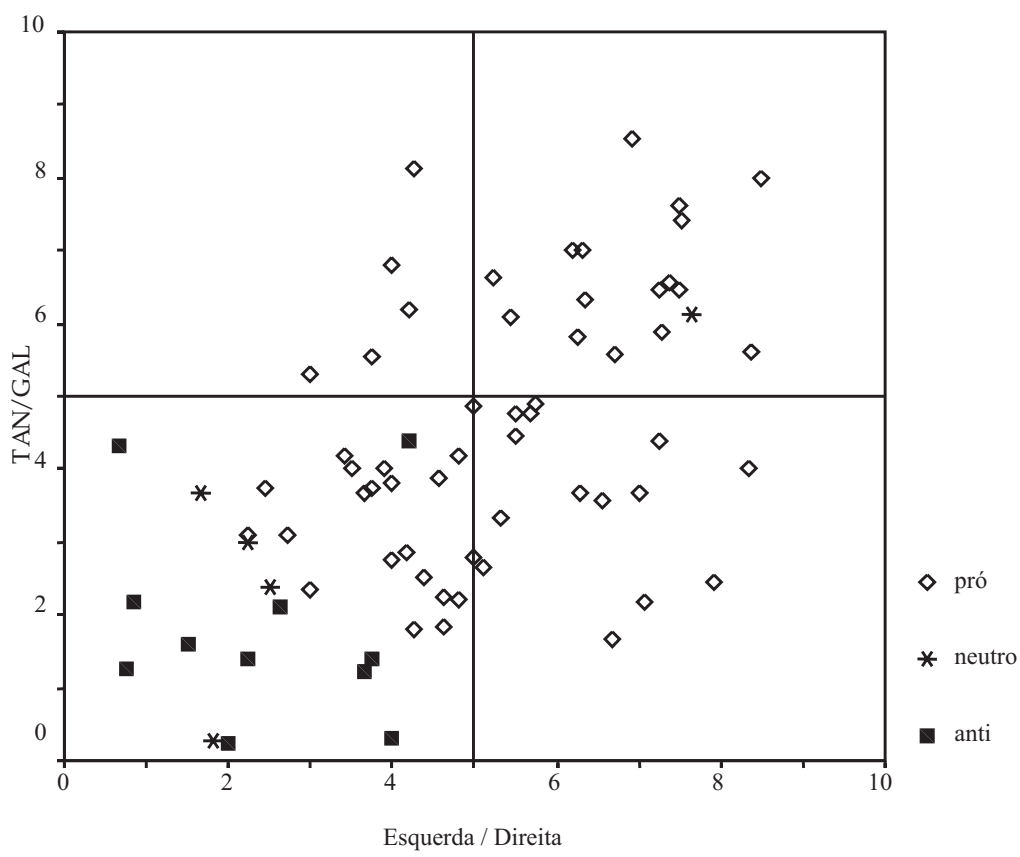

Fonte: Marks et alii (2004).

Nota 1: No Gráfico 5 vemos como se cruzam os dois alinhamentos: TAN/GAL (conservadores/verdes e alternativos) e esquerda/direita.

Nota 2: $\mathrm{N}=73$ partidos. Na escala de 1 (fortemente contra) a 7 (fortemente a favor da integração européia), partidos pró apresentam uma média entre 4,5 e 7; partidos neutros apresentam uma média entre 3,51 e 4,49; partidos anti apresentam uma média entre 1 e 3,5. 


\section{Gráfico 6}

Dimensões da Competição Partidária e Posicionamento da Integração Européia da Europa Ocidental

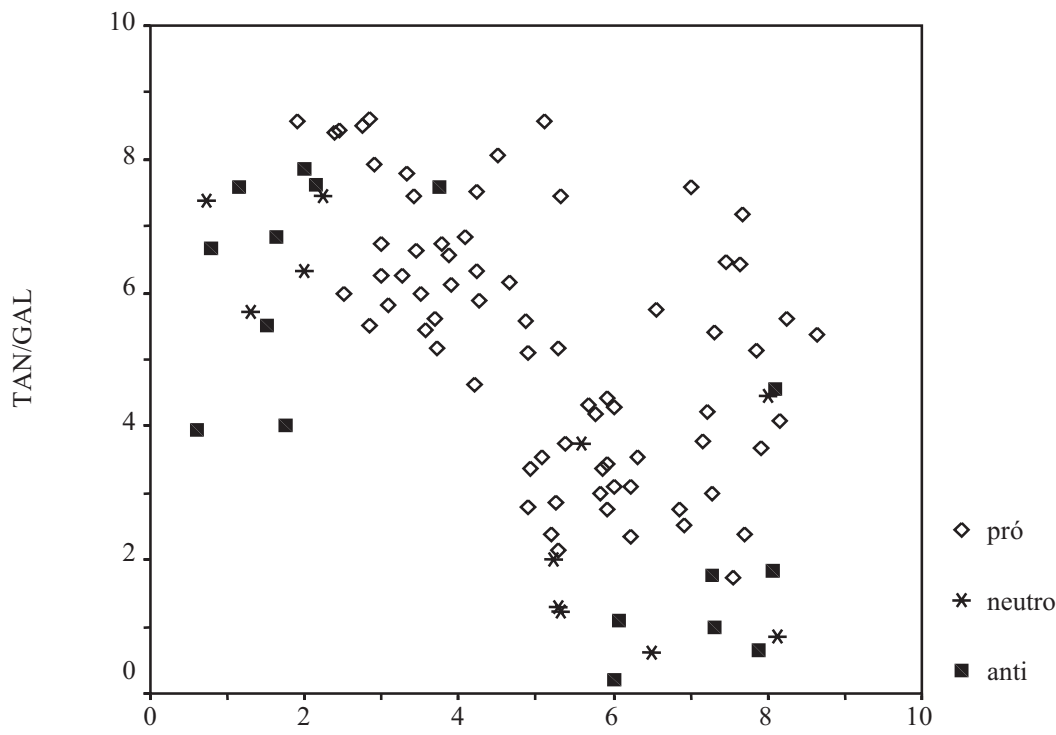

Esquerda / Direita

Fonte: Marks et alii (2004).

Nota 1: No Gráfico 6, vemos como se cruzam os dois alinhamentos: TAN/GAL (conservadores/verdes e alternativos) e esquerda / direita.

Nota 2: $\mathrm{N}=73$ partidos. Na escala de 1 (fortemente contra) a 7 (fortemente a favor da integração européia), partidos pró apresentam uma média entre 4,5 e 7; partidos neutros apresentam uma média entre 3,51 e 4,49; partidos anti apresentam uma média entre 1 e 3,5.

De modo geral, a posição partidária a respeito da integração européia é coerente e sistemática; logo, pode ser explicada desde o cruzamento das tradicionais dimensões de competição esquerda/direita e GAL/TAN. Neste cruzamento, é possível visualizar que perspectivas ideológicas afetam diferentemente o apoio à integração de acordo com os países, além do fato de alguns países europeus serem mais orientados pela dimensão da esquerda / direita e outros pela GAL/TAN. Com exceção de um, 16 partidos neutros e eurocéticos (assim enquadrados por estarem entre 4,5-7 pontos na escala criada para avaliar o apoio geral à integração) estão localizados no quadrante da Esquerda-TAN do Gráfico $5^{21}$, o que nos leva a inferir que a política européia tende a permanecer estruturada pela divisão entre direita-GAL versus esquerda-TAN. Entretanto, uma política regional ou supranacional que ressalta o mercado capitalista e valores cosmopolitas ao mesmo tempo 
gera novas demandas com características de hibridez. A defesa da autonomia nacional sobre certos mercados e a intolerância a respeito da quebra de fronteiras podem levar conservadores a terem interesses, junto às instituições européias, semelhantes aos interesses dos radicais de esquerda, os quais acusam a integração de antidemocrática e baseada no fortalecimento da economia das potências capitalistas européias. O objetivo da pesquisa que gerou a organização dos dados consultados e aqui reproduzidos nos gráficos 5 e 6 era o de identificar, principalmente, diferenças entre tendências do Leste e do Ocidente europeu, quanto à política de integração. Entretanto, a visualização da distribuição de preferências possibilita-nos também visualizar a distribuição das tendências de associação entre radicais de direita e de esquerda, em relação ao projeto da integração. Uma das conseqüências não previstas da integração européia vem sendo a capitalização de suas crises pelos defensores de uma nova direita não-tradicionalista, uma direita que é vista por Ignazi (2003:204) como subproduto da crise democrática e da crise da representação. Esta nova direita vem ganhando força e capacidade de articulação e organização no seio de alguns países (França, Noruega, Dinamarca, Holanda, Áustria, Itália e Bélgica) e, ainda que de modo brando, na Europa em geral, o que já vem sendo apontado por Ignazi desde a década de $1990^{22}$.

\section{NOVOS OPOSITORES E NOVOS MEIOS DE OPOSIÇÃO}

Partidos de esquerda como o sueco Vänsterpartiet ou o português Coligação Democrática Unitária opõem-se à política de mercado da UE e a acusam de ser o cavalo de Tróia do capitalismo internacional (Marks et alii, 2004). Por outro lado, os representantes e defensores do TAN opõem-se à integração pelas mesmas razões que se opõem à imigração. Estes rejeitam a assimilação de estrangeiros e defendem a soberania nacional, não pelos seus aspectos políticos e econômicos mas em função de valores intrínsecos relacionados a um nacionalismo radical.

Ainda que o Parlamento Europeu não exerça, de fato, um poder tão grande quanto o que a opinião pública européia avalia (Tostes, 2004), os pleitos regionais acabam por revelar sintomas da recepção do projeto de integração e de sua resistência. Naturalmente, além das eleições, outra forma de expressar preferências políticas, sociais, ideológicas e de identidades é através da organização e articulação de interesses em redes transnacionais. Assim, a literatura sobre networks e novas formas de associativismos têm enfatizado e demonstrado, através de dados e 
análises de pesquisas empíricas, que valores e crenças minoritárias e sem grande articulação no âmbito nacional podem se articular muito eficientemente e encontrar caminhos de institucionalização nos âmbitos internacional, transnacional e supranacional ${ }^{23}$. Assim tem ocorrido de fato também na região da integração européia, entretanto, isto não tem se dado apenas em relação a temáticas legítimas que implicam a defesa de direitos democráticos ou visam a uma organização justa da sociedade e da política. Ideais não-democráticos também se utilizam dos novos caminhos de articulação, proliferação de idéias, divulgação e influência política, de valores e de identidades; assim como grupos racistas, xenófobos e intolerantes vêm se fortalecendo no território europeu $^{24}$. Os intolerantes e defensores de modelos de segregação social ou racial têm se alinhado, oficialmente ou não, a representantes de partidos extremistas de direita (em alguns casos, com relações partidárias diretas, em outros são apenas simpatizantes e eleitores). A preferência por estes candidatos tem se apoiado também no fato de que os cidadãos estão absolutamente mal informados e alheios ao processo de integração e suas conseqüências.

A ignorância sobre a UE (revelada de várias formas e exemplificada nas pesquisas de opinião pública do Eurobarometer comentadas anteriormente e demonstradas nos gráficos 1 e 2, particularmente no que diz respeito às instituições) apareceu como o principal fator de rejeição da Constituição européia no âmbito nacional em vários $\operatorname{casos}^{25}$. Ainda que consideremos que nem todos os que discordam da idéia da construção de uma identidade coletiva regional votem em partidos de extrema direita, é certo que aqueles que o fazem não concordam em geral com a partilha de valores, crenças e identidade comum na região. Outro fator de escolha por um candidato de extrema direita surpreendeu a França em 2002, quando muitos franceses revelaram em pesquisas de opinião que o voto a Le Pen teria sido dado em protesto à política não-programática e à falta de ideologia e esperança na política. Além da questão específica da identidade, mas completamente associada a ela, deve-se considerar a profunda crise ideológica que atravessa o fim do bloco comunista (1989), mesmo período de aprofundamento da integração - eventos normalmente não associados, mas que certamente se influenciam reciprocamente. Dois fatos combinados, o fortalecimento econômico da Europa e o fim da URSS, geraram novas ondas migratórias. Como sabemos, membros de ex-repúblicas soviéticas começaram a migrar para a Europa Ocidental, e imigrantes de fora da região ocidental européia também buscaram se instalar na Europa inte- 
grada. Foi diante deste cenário que se alteraram muitas legislações nacionais sobre reconhecimento e aquisição de cidadania na década de 1990, restringindo-se juridicamente facilidades remanescentes para a imigração que havia, principalmente, em países colonizadores que mantinham o sistema jus sanguini como, por exemplo, a Itália, que reduziu as condições de reconhecimento de cidadania de descendentes de italianos.

Entre 1989 e 1999, a ocupação de cadeiras no Parlamento Europeu por representantes da extrema direita já havia preocupado a cúpula européia, a ponto de se iniciar uma Comissão de Inquérito no Parlamento Europeu para investigar o problema em 1989, que gerou o "Relatório sobre Racismo e Xenofobia: Radiografia do Radicalismo". O exame deste documento nos permite verificar o percurso do crescimento da extrema direita na Europa no início dos anos $1990^{26}$, o mesmo período de deliberação e implementação das medidas de aprofundamento da união política e criação da cidadania européia. Este período começa desde as negociações do Tratado de Maastricht, em sua fase de assinatura e ratificações nacionais (1991-93), e se estende até os efeitos de seus percalços. Esta fase ficou conhecida como "crise de Maastricht", que trouxe para a mídia e para os debates acadêmicos o tema do "déficit democrático da União Européia", como foi explicado anteriormente ${ }^{27}$.

Em 1997, o Eurobarometer publicou uma pesquisa especial bastante completa sobre o tema, intitulada "Racismo e Xenofobia na Europa" (o ano de 1997 ficou designado pela UE como "ano europeu contra o racismo" $)^{28}$. Os dados apresentados e a análise realizada por professores de universidades americanas e francesas (da Michigan State University e da École des Hautes Études en Sciences Sociales) já sugeriam um grau preocupante de racismo e xenofobia nos Estados-membros, pois a média dos europeus entrevistados que se assumiram como "totalmente racistas" ou "muito racistas" foi de 33\% - número muito alto, quando levamos em conta que a maioria dos racistas, de fato, não se assume como tal.

Em 1998, entrou em atividade o "European Monitoring Centre on Racism and Xenophobia" - EUMC, assumindo-se que a repressão e denúncia da intolerância se tornou uma prioridade na região. O EUMC é um observatório que funciona como uma estrutura ${ }^{29}$ que distribui funções e organiza atividades que têm em vista a conscientização dos problemas do racismo e da xenofobia na região, faz levantamento de dados, 
pesquisas e divulga informações na busca de estratégias de ação e soluções. Dentre suas atividades, existem relatórios anuais sobre trabalhos realizados pelo observatório e a divulgação da prática geral das situações em torno do racismo e xenofobia na UE. Finalmente, em 2000 foi criada uma importante network, a "Rede Européia de Informação sobre Racismo e Xenofobia" - RAXEN, que é considerada a ferramenta central de repressão ao racismo e xenofobia na UE. Esta rede serve como divulgadora de informações e dados sobre o problema, envolve a sociedade civil, e sua função é veicular "alertas rápidos" sobre a ocorrência de violências contra minorias religiosas, étnicas ou imigrantes.

Desde pelo menos 2001, os principais jornais e revistas nacionais e internacionais passaram a estampar com maior clareza alguns detalhes sobre o crescimento de uma nova direita radical em grande parte da Europa $^{30}$. O fato novo em torno desta questão é que as eleições européias de 2004 revelaram um pequeno aumento dessa representação radical de direita até então considerada preocupante, mas não crescente. Além disso, esse sintoma de crescimento não apareceu apenas nas eleições regionais, mas nos últimos anos, menos eventualmente, nas eleições nacionais.

O que mais importa em tudo isso é destacar que o problema do crescimento da extrema direita tornou-se um tema internacional de marcante característica regional européia, possivelmente em função da tentativa mais positiva no sentido de agregar cidadãos de diferentes origens em função de um projeto político comum. Assim, destinos de políticas partidárias nacionais passam a sofrer influência direta de um fenômeno que se expande desde as fronteiras eleitorais estatais e tem buscado se fortalecer no âmbito da representação européia. Embora os representantes dessa ideologia extremista de direita que se partidarizou, em defesa de programas políticos não-democráticos e antiintegracionistas, não se confundam necessariamente com os ativistas racistas, estes últimos são também seus eleitores ${ }^{31}$.

Paradoxalmente, a articulação entre os diversos grupos antiintegração, antiimigração e antidemocráticos em geral tem sido facilitada pelas novas possibilidades institucionais e representativas que surgiram com a integração européia através do Parlamento Europeu. Este efeito perverso não antecipado pelos defensores da integração política tem história e características ainda não identificadas completamente. Paralelamente, enquanto a Europa não constrói uma identidade coletiva 
clara, crises de identidade nacional se alimentam e são devoradas por discursos xenófobos e racistas. Forças xenófobas que antes agiam de modo fragmentado e desordenado perderam a vergonha e hoje se organizam em partidos nacionais, em grupos ideológicos europeus ${ }^{32}$, em moldes transnacionais e/ ou simplesmente votando em partidos extremistas para o próprio Parlamento Europeu. Estratégias de cooperação em função da resistência à integração se forjam ao mesmo tempo em que o governo da UE se empenha na constituição de uma união civil no seio das microrrelações sociais, e na base de seus impasses é possível identificar a importância da identidade política e social.

\section{CONCLUSÕES}

O processo de integração da UE há muito vem sendo identificado pelo seu déficit democrático, ou seja, não apenas porque algumas de suas instituições carecem de accountability ou porque seus membros não são eleitos diretamente pelos cidadãos mas, principalmente, porque há uma distância entre o sofisticado avanço nos âmbitos jurídico, econômico e institucional e a informação, a participação e a conscientização a respeito das conseqüências desse processo para as populações da região. A busca da correção do déficit democrático da UE e da legitimação do seu processo de integração social vem se revelando nas tentativas de construção e de uma cidadania única baseada em uma identidade cívica regional. Esta é a razão pela qual um projeto de construção de uma identidade coletiva regional (e supranacional) sempre esteve nos planos da integração. A idéia de comunidade política, que possui um projeto legal e cívico pluralista e democrático, deveria prevalecer nos novos debates sobre a construção de uma identidade coletiva que precisa ser inclusiva, sob o risco de se fortalecerem ainda mais as reações racistas e xenófobas entre membros dos Estados integrantes da UE. Será preciso consolidar a legitimidade da convivência de uma pluralidade de demoi dentro de um demos pluralista.

Segundo o Eurostat (Statistical Office of the European Comission), em $31 / 12 / 2001$, a UE contava com 379,4 milhões de habitantes, cerca de 1,5 milhão a mais do que em 2000. As pesquisas estimaram que mais de $70 \%$ deste crescimento da população se deu por fluxo migratório. Há uma estimativa atualizada, porém, sem contar com os novos Estados-membros ingressantes, que há mais de 3 milhões de imigrantes ilegais no território da UE - de variadas origens raciais, nacionais e culturais - e a convivência com eles suscita tolerância ou não. No decorrer 
desta convivência, evidências do fenômeno apontado por Walzer (1997) como "hifenização" - que se dá mais freqüentemente em "regimes de tolerância", em que se aceita a diferença, designados como "sociedades de imigrantes" - começam a aparecer: os afro-europeus, arab-europeans, asian-europeans etc. A "hifenização" é um fenômeno de tolerância e adaptação; trata-se da admissão de uma dupla identidade que não se contradiz e se complementa. Contudo, sabemos que outro efeito da mistura e sobreposição de identidades também é possível: a intolerância.

A eficácia dos radicais de direita não tem se revelado só a partir de propostas violentas para solucionar problemas sociais, mas também na capacidade de ação efetiva. Tem sido registrada uma crescente inserção desses ideólogos nas classes trabalhadoras, além da captação da simpatia de antiintegralistas em geral. Um importante exemplo da ação concreta e articulada da extrema direita pode ser dado por dois pequenos partidos suíços: Democratas Suíços e Lega. Eles obtiveram as 50 mil assinaturas necessárias para o referendo realizado em maio de 2000 sobre a aceitação ou não dos acordos bilaterais negociados com a UE pela Suíça. Esta consulta popular foi articulada pela extrema direita antiintegralista, mas, como sempre, eleitores de outras tendências (até mesmo de esquerda) votaram com a direita porque estes têm enfrentado mais claramente os dilemas do processo de unificação política e apresentado alternativas convincentes aos insatisfeitos.

Temos indícios suficientes para apontar duas implicações da integração regional européia, no que se refere à recepção social. A primeira é que na região da integração há resistências ideológicas, não simplesmente à integração mas também ao pluralismo e à democracia, e existem resistências históricas, sobre as quais podemos avaliar uma eventual graduação no âmbito das tradicionais dimensões políticas européias: radicais de esquerda e radicais de direita. Além disso, naturalmente, no que diz respeito à construção de uma nova identidade coletiva, mais ampla e inclusiva do que a identidade nacional, existem comportamentos e reações diferenciadas de acordo com a sociedade nacional. Mesmo que o mapeamento detalhado destas diferenças ainda não tenha sido realizado, a relação entre a consolidação de uma identidade coletiva européia única e uma cidadania legitimada pela aceitação popular é clara. Assim, a construção de uma unificação civil, além de ser necessária à eficácia da unificação legal e jurídica em amplos setores, é um projeto de legitimação da integração social na UE. 
A segunda implicação é que um projeto de integração legal tem sido a principal alavanca da integração política. É preciso não ignorar o fundamental papel exercido pela Corte de Justiça Européia ao alargar os poderes do Conselho Europeu e constituir um direito comunitário autônomo. A criação de uma "Constituição" tem, neste contexto, a missão clara de realizar um importante passo na direção da construção de uma identidade coletiva desprovida de resquícios culturalistas mas encarnada em uma valorização dos laços jurídicos e civis que garantiriam regras comuns mais claras e organizadas do que as que já vêm sendo seguidas, ainda que sem uma unidade "constitucional" supranacional. A rejeição deste modelo de integração jurídica, que pressupõe ou espera a construção de uma identidade civil, é uma forma de dizer não ao projeto inteiro da integração.

Historicamente, a idéia de cidadania é mais antiga do que a de nação, mas no Estado moderno os dois conceitos sempre se complementaram para justificar a atribuição de direitos e deveres de uma dada ordem jurídica e política. No caso da União, a identidade coletiva é fundamental para a cidadania, que por sua vez justifica a Constituição, ou um uso simbólico deste termo. O tratado designado como "Constituição" pretende substituir um ordenamento jurídico construído ao longo de meio século por uma série de tratados, acordos e decisões jurisprudenciais da Corte de Justiça Européia, regras criadas em geral no âmbito de instituições não-representativas. Uma idéia de Constituição pressupõe uma unidade e o reconhecimento do projeto de integração legal da Europa, conseqüentemente com poder simbólico de fortalecer os laços de coexistência entre os povos dos diferentes Estados-membros.

(Recebido para publicação em janeiro de 2006) (Versão definitiva em abril de 2006) 


\section{NOTAS}

1. Uma ampla literatura vem se debruçando sobre o crescente sentimento antieuropeísta e antiintegracionista e sua relação com o crescimento dos movimentos de direita e extrema direita na Europa. Ver, por exemplo, Chamorel, 2000; Duncan, 1999; Muller, 2000; Hainsworth, 1999.

2. O "interesse comunitário" já estava previsto no Tratado de Paris, de 1951, que criou a Comunidade Econômica do Carvão e do Aço - CECA .

3. Sobre o debate a respeito da inexistência de um demos europeu ver, por exemplo: Cederman (2000); Casanova (2005); Karnoouh (1998).

4. O processo de ratificação do Tratado de Maastricht (1992-93), que reformou os tratados fundadores da União Européia e criou a cidadania única européia, gerou uma crise na integração e revelou um abismo entre a aceleração da integração legal e a integração social na região. Para maiores informações sobre este debate, ver Chryssochoou (1996); Wilterdink (1993); Tostes (2004).

5. Ver Goldstein e Keohane (1993); Calhoun (1994); Krause e Renwick (1996); Lapid e Kratochwil (1996).

6. Particularmente, seus aspectos de supranacionalidade são os que mais exigem legitimação pela identidade coletiva. Entretanto, é importante destacar que considero que o processo de integração possui características de intergovernabilidade e de supranacionalidade. Além disso, esse processo mistura modelos institucionais existentes com novas fórmulas de organização e participação e possui um ordenamento jurídico constitucional híbrido. Por tudo isso, não creio que haja outra forma de organização política comparável à UE; logo, não há também uma perspectiva teórica única capaz de atribuir teor explicativo a todos os aspectos de sua estrutura (regime político, instituições, direito, modelo regulatório etc.). Para o desenvolvimento desta perspectiva, ver Tostes (2004).

7. O Conselho Europeu é uma reunião de cúpula de chefes de Estado e de governo europeus que ocorre pelo menos duas vezes por ano para definir diretrizes políticas comuns para seus membros.

8. O Eurobarometer é o maior instituto de opinião pública da Europa atualmente e vem mapeando a percepção das sociedades dos Estados-membros sobre os mais variados aspectos da integração e da política européia de modo geral. Acessível no site: http:/ / ec.europa.eu.

9. Mais sobre o papel e funções das instituições européias, cf. Tostes (2004).

10. A Dinamarca só conseguiu aprovar a ratificação em segunda consulta popular, a França ratificou por uma margem mínima, e o povo norueguês rejeitou definitivamente a União Européia - não fazendo parte do bloco atualmente.

11. Foi no Conselho Europeu de Edimburgo, em 11 e 12 de dezembro de 1992, que ficou decidido o Protocolo das concessões de regras especiais para a Dinamarca.

12. Eurocéticos ou europessimistas são designações usadas indiscriminadamente na literatura acadêmica e pela mídia para se referir àqueles que não crêem no sucesso da integração, bem como aos que são contra a integração. O euroceticismo tornou-se uma área de pesquisa no campo dos estudos europeus (Aggart e Szcezerbiak, 2004). 
13. Quando comparamos os resultados do grau de apoio à Constituição de 2004 e 2005 por país (Eurobarometer, n은 2005 ), podemos verificar que houve queda em quase todos os Estados-membros, com destaque para Holanda, Áustria e República Tcheca, tendo crescido apenas na Hungria e Itália.

14. Em países como a França, o debate sobre a Constituição ocupou todos os espaços da sociedade civil, houve empenho das instituições de ensino e do governo no sentido de divulgar e conscientizar a sociedade civil a respeito do significado, conteúdo e conseqüências do Tratado da Constituição.

15. Só o Eurobarometer faz cerca de quatro sondagens por ano sobre os mais variados temas da integração.

16. O nacionalismo do tipo culturalista é o mesmo que influenciaria a Alemanha, Itália, os países eslavos, e mesmo a França pós-revolucionária, sob os auspícios de Napoleão.

17. Não foi por acaso que o ideal revolucionário francês encaminhou no continente sua pretensão de constituir-se como berço de um ideal europeu e universal: o que era bom para a França poderia ser bom para toda a humanidade. Essa percepção surge na Revolução Francesa e atravessa o processo de integração que se inicia após as guerras mundiais. Pierre Nora chama de "hipoteca" da Revolução a idéia da transformação da soberania monárquica em soberania nacional, com todas as conseqüências aí implicadas (cf. Furet, 1988:803-814). Com isso, reconhecemos uma singularidade da concepção de nação no discurso revolucionário, seu alcance e o poder que adquiriu desembocarão em um modelo de soberania que não será questionado até a crise dos Estados nacionais, a qual arrasta consigo a crise, não só da concepção de soberania nacional, mas do próprio modelo de Estado democrático moderno, da representação política, da legitimidade democrática, da liberdade etc.

18. O nacionalismo, em uma de suas vertentes concorrentes, quais sejam, construtivista (nacionalismo político) e naturalista (nacionalismo culturalista), não vinha sendo questionado até a intensificação da globalização, que trouxe meios de ação transnacional e um aumento de atores não-estatais, por condições materiais e tecnológicas de ação e organização.

19. Enquanto este artigo se submetia ao processo de aceitação para esta publicação, a PS: Political Science \& Politics, de abril de 2006, dedicava-se especialmente ao tema da rejeição da Constituição européia, na qual podem ser encontrados dados recentes que contribuem para os argumentos aqui apresentados e ratificam a extrema importância da investigação sobre as crises da União Européia à luz de uma perspectiva histórica e social sistemática.

20. Na pesquisa consultada para este artigo, feita pela University of North Carolina UNC, foram examinados 171 partidos políticos em 23 dos Estados-membros.

21. Os critérios e a explicação das variáveis utilizadas estão na pesquisa original, parte dela acessível no site da UNC, que poderá ser conferida de modo mais completo brevemente, pois um artigo sobre a pesquisa, com o título "Party Competition and European Integration in East and West. Different Structure, Same Causality", tem sua publicação prevista para 2006, na Comparative Political Studies.

22. Cf., por exemplo, Ignazi (2003); Ignazi e Perrineau (2000); Ignazi (1996); Ignazi e Ysmal (1992).

23. Ver por exemplo, Keck e Sikkink, 1998 e Diani e McAdam, 2003. Ver também a situação da "sociedade civil global" mapeada anualmente nos Yearbooks do Centre of Glo- 
bal Governance, London School of Economics - LSE. Em particular em Glasius, Kaldor e Anheier (2002), podemos conferir uma série dedicada exclusivamente a analisar os aspectos controversos e "esquizofrênicos" das mobilizações temáticas e transnacionais e as evidências disso no contexto dos ataques de 11 de setembro de 2001 e do acirramento da crise no Iraque.

24. Segundo o Guia da Europa Negra, do espanhol Manoel Floretín, atualmente o número de organizações que não defendem ideais democráticos como as organizações neonazistas, ultranacionalistas, de extrema direita e afins já são mais de 300 na Europa do Ocidente. Nos últimos cinco anos, as home pages de organizações neonazistas e de extrema direita em geral aumentaram cerca de 10 vezes, tendo se tornado a principal ferramenta de articulação e comunicação em função da falta de controle jurídico e de regras de restrições aos conteúdos dos sites, ou seja, mesmo havendo restrições para impressão, venda ou mesmo representação partidária de idéias nacional-socialistas em muitos países, a tecnologia da rede de informações e comunicação e a ação transnacional permitem novas formas de organização de idéias não-democráticas sob os auspícios dos Estados democráticos.

25. Uma pesquisa do Eurobarometer realizada na Holanda pós-referendo e publicada em junho de 2005 (Flash EB n ${ }^{\circ} 172,2005$ ), revelou que a principal razão do voto "não" na Holanda (32\% dos votantes) se deu em função da falta de informação, 19\% temiam a perda da soberania nacional, e $14 \%$ votaram "não" como forma de se opor ao governo.

26. Jornais do mundo inteiro divulgaram este relatório naquela ocasião, disponível nos arquivos da Comissão da UE.

27. A literatura sobre a integração na Europa se dobrou completamente para analisar os efeitos de Maastricht; apenas para mencionar alguns títulos importantes: Christiansen (1997); Chryssochoou (1996); Cafruny e Rosenthal (1992); Maurer (1999); Weiler, Haltern e Mayer (1995:4-39); Wilterdink (1993:119-136).

28. EB Special Report $n^{\circ} 47.1,1997$.

29. Ver conceito de McAdam (cf. Diani e McAdam, 2003).

30. Apenas para exemplificar, cf. Veja, 23/5/2001 sobre a eleição de Silvio Berlusconi para primeiro-ministro na Itália); Folha de S. Paulo, 14/5/2002 sobre os eventos: candidatura e assassinato de Pim Fortuyn; The Economist de 4/7/2002 (Holanda); Veja, 1/5/2002 sobre Le Pen na França, direita em Portugal, Áustria e Dinamarca; O Estado de S. Paulo, edição 206 de 29 / 4 / 2002 sobre o declínio da onda rosa da socialdemocracia na Dinamarca, Noruega, Holanda, Portugal, França, Itália e Alemanha; Folha de S. Paulo de 22/9/2002, que mostra que o socialismo perdeu espaço para a direita e que enquanto em 199813 dos 15 governos da UE eram governados pela esquerda ou centro-esquerda, em 2002 apenas cinco países estavam sendo governados por socialdemocratas ou coalizões de centro-esquerda.

31. Um bom exemplo disso é o partido da Frente Nacional - FN, que agrega amplos setores da direita como católicos integralistas, os quais buscam reintegrar antigos e tradicionais valores e rituais da Igreja, como missa em latim etc., monarquistas e fascistas.

32. Ainda não existem partidos europeus, logo, a divisão dos trabalhos no Parlamento Europeu se dá pela via de agrupamentos partidários que têm designação própria segundo suas tendências ideológicas. Assim, existem grupos que se associam em defe- 
sa do fim da integração; logo, articulam interesses pela desconstituição da UE, em muitos casos por razões xenófobas.

\section{REFERÊNCIAS BIBLIOGRÁFICAS}

AGGART, Paul e SZCZERBIAK, Aleks. (2004), “Contemporary Euroscepticism in the Party Systems of the European Union Candidate States of Central and Eastern Europe". European Journal of Political Research, vol. 43, pp.1-27.

ADLER, Emmanuel. (1992), “Europe's New Security Order: A Pluralistic security community", in B. Crawford (ed.). The Future of European Security. Berkeley, Center for German and European Studies.

. (1999), “O construtivismo no estudo das relações internacionais”. Lua Nova, no 47.

ANDERSON, Benedict. (1991), Imagined Communities. Reflections on the Origins and Spread of Nationalism. London/New York, Verso.

AZIZ, Miriam. (2002), “EU Citizenship: Spheres of Belonging and the Politics of Dispossession". Working Paper, no 68. Florence, European University Institute.

BARTOLINI, Stefano e MAIR, Peter. (1990), Identity, Competition, and Electoral Availability: The Stabilization of the European Electorate, 1885-1985. Cambridge, Cambridge University Press.

BRINK, Rinke van den. (1996), L'Internationale de la Haine, Paroles d'Extrême Droite, Belgique, France, Italie. Bruxelles/Liège, Éditions Luc Pire/l'ASBL Vent du Nord, Vent du Sud.

CALHOUN, Craig. (ed.). (1994), Social Theory and the Politics of Identity. Oxford/ Cambridge, Blackwell.

CASANOVA, José. (2005), "Regionalism, European Secular Identities, and European Integration". Disponível em <http://www.eurozine.com> (acessado em $30 / 5 / 2006)$.

CEDERMAN, Lars-Erik. (2000), "Nationalism and Bounded Integration: What it Would Take to Construct a European Demos". Working Paper, no 34, European University Institute/Robert Schuman Centre of Advanced Studies - RSCAS.

CHAMOREL, Patrick. (2004), "Anti-Europeanism and Euroscepticism in the United States". Working Paper, no 25, European University Institute/Robert Schuman Centre of Advanced Studies - RSCAS.

CHRYSSOCHOOU, Dimitris N. (1996), "Europe's Could-be Demos: Recasting the Debate". West European Politics, vol. 19, no 4, pp. 787-801.

DEUTSCH, Karl W. et alii. (1957), Political Community in the North Atlantic Area: International Organization in the Light of History Experience. Princeton, Princeton University Press. 


\section{Ana Paula Tostes}

DIANI, Maria; McADAM, Doug. (2003), Social Movements and Networks. Oxford, Oxford University Press.

DUNCAN, William. (1997), “Racism and Xenophobia in Europe”, in G. Barret (ed.), Justice Cooperation in the European Union: The Creation of an European Legal Space. Dublin, Institute of European Affairs.

EISENSTADT, Shmuel N. e Bernhard Giesen. (1995), "The Construction of Collective Identity". European Journal of Sociology, vol. 36, pp. 72-102.

EUROBAROMETER Surveys. On line. Internet. Acessível: http:/ /ec.europa.eu/public_ opinion/archives.

GIESEN, Bernhard. (1999), "Collective Identity and Citizenship in Germany and France", in K. Elder e B. Giesen (eds.), European Citizenship and the National Legacies. Oxford, Oxford University Press.

FINNEMORE, Martha. (1996), National Interests in International Society. Ithaca, Cornell University Press.

FLANAGAN, Scott C. e AIE-RIE Lee. (2003), "The New Politics, Culture Wars, and the Authoritarian-Libertarian Value Change in Advanced Industrial Societies". Comparative Political Studies, vol. 36, pp. 235-270.

FLANAGAN, Scott C. (1987), "Value Change in Industrial Societies". American Political Science Review, vol. 81, pp. 1.303-1.318.

FRANKLIN, Mark N. (1992), "The Decline of Cleavage Politics", in M. Franklin et alii, Electoral Change: Responses to Evolving Social and Attitudinal Structures in Western Europe. Cambridge, Cambridge University Press, pp. 383-405.

, EIJK, C. Van Der e MARCH, M. (1995), "Referendum Outcomes and Trust in Government: Public Support for Europe in the Wake of Maastricht". West European Politics, vol. 18, no 3, pp. 101-117.

GLASIUS, M., KALDOR, M. e ANHEIER, H. (2002), Global Civil Society Yearbook 2002. New York/Oxford, Oxford University Press.

GOLDSTEIN, J.e KEOHANE, R. O. (ed.) (1993), Ideas and Foreign Policy: Beliefs, Institutions and Political Changes. Ithaca, Cornell University Press.

HAAS, Ernst B. (1958), The Uniting of Europe: Political, Social and Economic Forces 1950-1957. Stanford, CA, Stanford University Press.

HAINSWORTH, Paul. (1999), "The Right: Divisions and Cleavages in Fin de Siècle France”. West European Politics, vol. 22, no 4 .

HARTLEY, T.C. (1998), The Foundations of European Community Law. New York, Oxford University Press.

HIX, Simon e LORD, Christopher. (1997), Political Parties in the European Union. New York, St. Martin's Press.

IGNAZI, Piero. (1996), "The Intellectual Basis of Right-Wing Anti-Partytism". European Journal of Political Research, vol. 29, no 3, pp. 279-296.

. (2003), Extreme Right Parties in Western Europe. Oxford, Oxford University Press. 
e PERRINEAU, P. (2000), “L'Extreme Droite en Europe: Marginalité du Neo-fascisme et Dynamique de l'Extrême Droite Post-industrielle", in G. Grunberg, P. Perrineau e C. Ysmal (orgs.), Le Vote des Quinze. Les Élections Européennes du 13 Juin 1999. Paris, Presses de Sciences Po, pp. 223-242.

e YSMAL, C. (1992). "New and Old Extreme Right Parties. The French Front National and the Italian Movimento Sociale". European Journal of Political Research, vol. 22, no 1, pp. 101-121.

INGLEHART, Ronald. (1977), The Silent Revolution. Princeton, Princeton University Press.

JANSSON, Per. (1997), “Identity-Defining Practices in 'Thucydides'. History of Peloponnesian War". European Journal of International Relations, vol. 3, no 2, pp. 147-165.

KARNOOUH, Claude. (1998), “Logos without Ethos: On Interculturalism and Multiculturalism". Telos, no 110, pp. 119-133.

KECK, Margaret E. e SIKKINK, Kathryn. (1998), Activists beyond Borders. Advocacy Networks in International Politics, London, Cornell University Press.

KOHN, Hans. (1963), A Era dos Nacionalismos. Rio de Janeiro, Fundo de Cultura (tradução de Waltensir Dutra).

KRAUSE, J. e RENWICK, N. (eds.). (1996), Identities in International Relations. London, Macmillan Press Ltd.

LAFFAN, Brigid. (1996), “The Politic of Identity and Political Order in Europe”. Journal of Common Market Studies, vol. 34, no 1, pp. 81-101.

LAPID, Yosef e KRATOCHWIL, Friedrich (eds.). (1996), The Return of Culture and Identity in RI Theory. London, Lynne Rienner.

LIPSET, Seymour Martin e ROKKAN, Stein. (1967), “Cleavage Structures, Party Systems and Voter Alignments: An Introduction", in S. M. Lipset e S. Rokkan (eds.), Party Systems and Voter Alignments: Cross-National Perspectives. New York, The Free Press, pp. 1-64.

MARKS, G., HOOGLE, L., NELSON, M. e EDWARDS, E. (2006), “Party Competition and European Integration in East and West. Different Structure, Same Causality". Comparative Political Studies, vol. 39, no 2, pp. 155-175.

MARKS, G., WILSON, Carole e RAY, Leonard. (2002), “National Political Parties and European Integration". American Journal of Political Science, vol. 46, pp. 585-594.

MAURER, Adreas. (1999), “(Co-)Governing after Maastricht: The European Parliament's Institutional Performance 1994-1998". Working Paper, no 104, Luxembourg, European Parliament, Directorate Generale for Research, Political Series.

MUDE, Cas. (1996), "The War of Words Defining the Extreme Right Party Family". West European Politics, vol. 19, no 2, pp. 225-248.

MÜLLER, Wolfgang C. (2000), “The Austrian General Elections of 1999 - A Shift to the Right". West European Politics, vol. 23, no 3.

RISSE-KAPPEN, Thomas. (1994), “Ideas Do Not Float Freely: Transnational Coalitions, Democratic Structures, and the End of the Cold War". International Organization, vol. 48 , pp. $185-214$. 


\section{Ana Paula Tostes}

. (1995), Cooperation among Democracies: The European Influence on U.S. Foreign Policy. Princeton, Princeton University Press.

. (2000), Regionalism and Collective Identities: The European Experience. Trabalho apresentado no workshop El Estado del Debate Contemporáneo en Relaciones Internacionales. Buenos Aires, Argentina, 27-28 de julho.

SMISANS, Stijn. (2004), “The EU's Schizophrenic Constitutional Debate: Vertical and Horizontal Decentralism in European Governance". Working Paper, no 32, European University Institute/Robert Schuman Centre of Advanced Studies - RSCAS.

SMITH, Anthony D. (1992), "National Identity and the Idea of European Unity". International Affairs, vol. 68, no 1, pp. 55-76.

TAGGART, Paul. (1998), "A Touchstone of Dissent: Euroscepticism in Contemporary Western European Party Systems". European Journal of Political Research, vol. 33, no 3, pp. 363-388.

TOSTES, Ana Paula. (2001), “Supranacionalidade e Democracia: O Caso Europeu”. Contexto Internacional, vol. 23, no 1, pp. 35-76.

. (2004), União Européia: O Poder Político do Direito. Rio de Janeiro, Renovar.

WALLACE, William e SMITH, Julie. (1995), “Democracy or Technocracy? European Integration and the Problem of Popular Consent". West European Politics, vol. 18, no3, pp. 137-157.

WALZER, Michael. (1967), "On the Role of Symbolism in Political Thought”. Political Science Quarterly, vol. 82, no 2, pp. 191-204.

. (1997), On Toleration. New Haven/London, Yale University Press.

WEILER, J. H. H., HALTERN, Ulrich R. e MAYER, Franz C. (1995), “European Democracy and its Critique". West European Politics, vol. 18, no 3, pp. 4-39.

WENDT, A. (1999), A Social Theory and International Politics. Cambridge, Cambridge University Press.

WILTERDINK, Nico. (1993), "An Examination of European and National Identity". Archives Européennes de Sociologie, tomo XXXI, no 1, pp. 119-136. 


\section{ABSTRACT \\ Why not a European Constitution?}

This article explores the reasons behind the fact that European institutions have decided to establish a new Constitutional treaty, while portions of the national societies have shown signs of resistance to it. The hypothesis is that causes similar to those involved in previous crises, like Maastricht, also help explain the current crisis, and that problems of supranational legitimization should also be elucidated by the analysis of transnational articulations in the region. By verifying distortions in the social perception of the role of institutions and the Constitution and the growth of the extreme right in Europe, interpreted in the historical context of integration, we highlight the importance of identity and the relationship between the lack of social unity and the movements against integration, calling for a change in the current dimensions of European politics.

Key words: European Union; European Constitution; collective identity; extreme right

\section{RÉSUMÉ \\ Pourquoi pas une Constitution Européenne?}

Dans cet article, on examine les raisons qui font que des institutions européennes ont décidé de rédiger un nouveau traité constitutionnel tandis que quelques-unes des sociétés nationales lui opposent une résistance. On part de l'hypothèse que des causes semblables à celles de crises précédentes, comme ce fut le cas de Maastricht, expliquent aussi la crise actuelle, et que les questions de la légitimité supranationale doivent être précisées par l'analyse des rapprochements transnationaux dans la région. En cherchant à vérifier les distorsions de la perception sociale sur le rôle des institutions et de la constitution, ainsi que sur le renforcement de l'extrême droite dans la région, interprétés dans le contexte historique de l'intégration, on a conclu sur l'importance de l'identité et la relation du manque d'unité sociale avec les mouvements de résistance à l'intégration qui présentent un changement nécessaire dans le cadre de la politique européenne actuelle.

Mots-clé: Union Européenne; Constitution Européenne; identité collective; extrême droite 